\title{
Sodium Acetate
}

National Cancer Institute

\section{Source}

National Cancer Institute. Sodium Acetate. NCI Thesaurus. Code C47720.

The trihydrate sodium salt of acetic acid with alkalinizing, diuretic and electrolyte replacement properties. Following absorption, sodium acetate generates sodium bicarbonate, thereby raising blood and urine $\mathrm{pH}$. In addition, this agent may increase serum sodium concentration. 